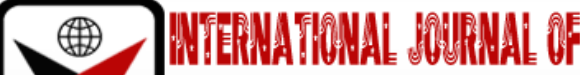

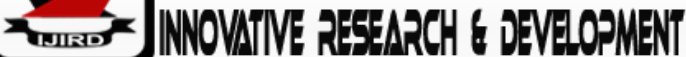

ISSN 2278 - 0211 (Online)

\section{Assessment of Knowledge, Attitude and Practices of Residents and Stakeholders' Opinionon Faecal Sludge Management in Abeokuta South Local Government, Ogun State, Nigeria}

Dr. Soyingbe A.A.
Senior Lecturer, Department of Environmental Health Sciences,
College of Environmental Health, Ilese, Ogun State, Nigeria
Dr. Terebo, O.
Senior Lecturer, Department of Environmental Health,
School of Health Technology, Akure, Ondo State, Nigeria
Dr. Olujimi 0.0.
Senior Lecturer, Department of Environmental Management \& Toxicology,
Federal University of Agriculture, Abeokuta, Ogun State, Nigeria
Dr. Olayinka O.
Reader, Department of Environmental Management \& Toxicology,
Federal University of Agriculture, Abeokuta, Ogun State, Nigeria
O. Bamgbose
Professor, Department of Environmental Management \& Toxicology,
Federal University of Agriculture, Abeokuta, Ogun State, Nigeria

\begin{abstract}
:
This study adopted descriptive structured questionnaire to elicit information on faecal sludge management from 399 household heads in Abeokuta South Local Government Area, Ogun State. The respondents were of 41-50 years, 54.6\% were males and $29.8 \%$ had secondary education. Most houses (93.5\%) had toilet facilities with pit-latrine (49.9\%) the most common disposal method. Attitudinal score was $9.5 \pm 2.7$ and $51.9 \%$ had positive attitude towards faecal management. No significant $(P>0.05)$ difference between respondents' knowledge of faecal management and demographic characteristics whereas, the level of education was significantly $(P<0.05)$ associated with the respondents' attitude to faecal management. No significant difference $(P>0.05)$ between respondent'sfaecal sludge management practices and sex whereas there was significant difference $(P<0.05)$ between respondent's education level, types of toilet facilities, status and re-use options. Conclusively, study area is of medium density with mixture of high- and low-income populations which make their knowledge, attitude and practices of faecal management encouraging.
\end{abstract}

Keywords: Emptier, faecal sludge, types of toilet facilities, knowledge, management

\section{Introduction}

Faecal sludge management in the third world presents with a lot of difficulties. Analyzing the main problems identified along the faecal sludge management path therefore must include collection, haulage, treatment, and reuse or disposal.Faecal sludge management therefore involves all the activities related to the management of sludge from On-site sanitation systems: pit emptying, faecal sludge haulage, treatment and disposal site. It also includes the actors of the faecal sludge management: pits/septic tanks owners, manual emptier, emptying enterprises, treatment plant manager/operators, farmers (uses of the treatment products), local municipal and national authorities involved in environmental and health management (Montenegro and Strauss, 2002).

For instance, in the city of Lagos, the main sanitation systems available in the major residential areas of metropolitan Lagos are the traditional pit latrines and water closet septic tank. However, the major environmental concerns in Lagos metropolis are the collection, treatment and disposal of sewage and other related wastewater. Although the use of pail system (bucket latrine) in Lagos metropolis has been banned, yet the government machinery via the Sewage and Water Department of the State Ministry of Environment has currently not devised an efficient system of disposing of the seepage from septic tank / soak ways. Therefore, all these untreated excreta, together with the commercial and industrial wastewater are usually discharged into the Lagos lagoon system, other surface water points and in some cases find their ways into ground water. This brings about the risks of water pollution and destroys marine animal and aquatic 
food sources in the metropolis. The domestic water pollution problems result from the fact that in some areas of the metropolis the water table is very high and even some areas the water table is near the surface, for example within 3 meters of digging you will get water. The soil is usually porous and this increases the chances of sewage and other wastewater infiltrating and polluting ground water and well water, which are the major sources of water in many areas (Iwugoet al, 2003).

Montangero and Strauss (2002) have identified problems of uncontrolled dumping of faecal sludge in the urban environment. These are high emptying fees, inaccessible pits as well as long haulage distance. Other identified causes include the lack of political will, legal constraints on faecal sludge management, and lack of allocation of clear responsibilities to the different stakeholders, as well as the non-integration of faecal sludge management in urban planning. As a consequence, excreta-related diseases are endemic in most cities in developing countries, thereby reducing income and the quality of life of urban population.

It is therefore pertinent to study faecal sludge and Waste Management system in especially the urban areas in the developing world with a view to finding solutions and to forestall associated environmental health risks. Therefore, the health implication of improper human excreta management makes this investigation imperative. Abeokuta is very fastgrowing urban center where modern urban growth and sprawl has overtaken hitherto rural communities and settlement without totally transforming them and as such traditional human excreta management exists side by side with modern excreta management systems.

Therefore, this study assessed the knowledge, attitude and practices of residents and stakeholders' opinion on faecal sludge management in Abeokuta South local Government area, Ogun State.

\section{Methodology}

\subsection{Description of the Study Area}

The study area is Abeokuta South Local Government area, Ogun State, Southwestern Nigeria with population of 250, 295 (2006 Census). It is divided into fifteen wards namely: -Ake ward,Adatan/Asero/ Car wash,Okero, Kesi/Emere, Ijemo, Itoko, Ijaye/Idi-aba, Ijeun, Leme, Isale-Ijeun/Iporo-Ijeun, Kemta/Okebode, Imo/Igbein, Igbore/Ago-Iba, Kolobo/Adigbe and Omida/Ibara (Figure 1). The study adopted descriptive design where self-structured questionnaires and Key Informant Interview were used to obtain information from three hundred and ninety-nine (399) household heads and other stakeholders (Emptiers and Chief Environmental Health Officer. The study was limited in scope to randomly selected seven wards out of the fifteen wards of Abeokuta south local government area. The selected wards were: Adatan/Asero/Car wash, Kenta/Oke bode, IsaleIjeun, Kolobo/Adigbe, Itoko, Imo/Igbehin and Omida/Ibara (figure 1).

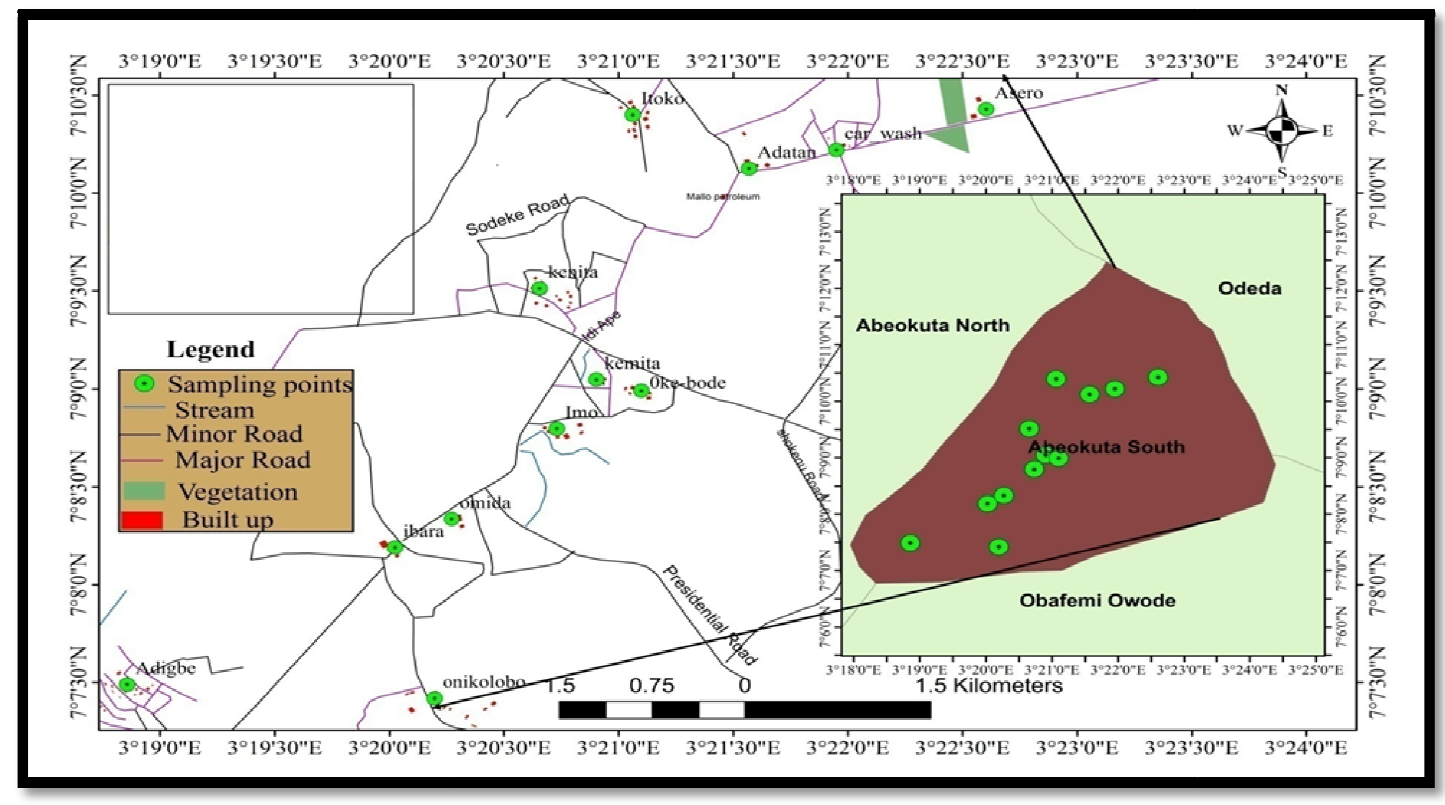

Figure 1: Location of Ogun State Coordinates: $7^{\circ} 00^{\prime} \mathrm{N} 3^{\circ} 35^{\prime} \mathrm{E}$

Source: Field Study, 2016

\section{Results and Discussion}

\subsection{Socio-Demographic Characteristics}

Table 1 and Figure 2 show the results of demographic information of the respondents. Based on the age distribution $38.0 \%$ were of $41-50$ years age range while, more than half of the respondents were male (54.6\%) with $29.8 \%$ having had secondary education. More tenants (81.0\%) were interviewed than the landlords of the houses (16.1\%). From Figure 2, majority of the respondents $(89.4 \%)$ had their monthly income equal to or below forty thousand naira (N40,000: $00)$ and very few (0.60\%) earned above N160,000:00. 
That $54.6 \%$ of the respondents were male was not in consonance with the findings of Nkansah, (2009) who recorded about $97 \%$ of the household responses to be male in the study conducted in Tamale city of Ghana. Educational status of the respondents revealed that majority $(72.25 \%)$ had formal education. This corroborated with the report of Okechukwuet al., (2012) and Soyingbeet al., (2015) in Northern Ghana and Ijebu-ode metropolis respectively.

This study showed that majority of the respondent's level of income could also influence the choice of their faecal sludge disposal. Sivakumar and Sugirtharan (2010) reported that family size and income were the most significant factors affecting the quantity of faecal sludge generation. Grover and Singh (2014) revealed that a city with medium or low income may be significantly different from a similar city with higher income in terms of faecal sludge management. They also reported that there is a clear similarity between cities with similar income levels in respect of faecal sludge management.

\begin{tabular}{|c|c|c|}
\hline $\begin{array}{l}\text { Socio-Demographic } \\
\text { Characteristics }\end{array}$ & Subgroups & Frequency (\%) \\
\hline \multirow[t]{5}{*}{ Age (year) } & $\leq 20$ & $8(2.2)$ \\
\hline & $21-30$ & $52(13.1)$ \\
\hline & $31-40$ & $148(37.2)$ \\
\hline & $41-50$ & $152(38.0)$ \\
\hline & $>50$ & $\begin{array}{c}38(9.5) \\
399(100) \\
\end{array}$ \\
\hline \multirow[t]{2}{*}{ Sex } & Male & $228(54.6)$ \\
\hline & Female & $\begin{array}{l}194(45.4) \\
399(100)\end{array}$ \\
\hline \multirow[t]{4}{*}{ Educational status } & No education & $72(16.8)$ \\
\hline & Primary education & $75(18.3)$ \\
\hline & Secondary education & $124(29.8)$ \\
\hline & Tertiary education & $113(27.1)$ \\
\hline \multirow[b]{2}{*}{ Total } & Quranic education & $12(2.8)$ \\
\hline & Vocational education & $\begin{array}{c}26(5.3) \\
399(100)\end{array}$ \\
\hline \multirow[t]{2}{*}{ Respondent status } & Owner & $76(16.1)$ \\
\hline & Tenant & $\begin{array}{l}323(81.0) \\
399(100)\end{array}$ \\
\hline \multirow[t]{4}{*}{ Occupation } & $\begin{array}{c}\text { Civil service } \\
\text { Trading } \\
\end{array}$ & $\begin{array}{c}40(10.0) \\
275(68.9)\end{array}$ \\
\hline & Farming & $22(5.5)$ \\
\hline & Teaching & $26(6.5)$ \\
\hline & Student & $\begin{array}{c}36(9.0) \\
399(100)\end{array}$ \\
\hline
\end{tabular}

Table 1: Socio-Demographic Information of the Respondents in the Study Area

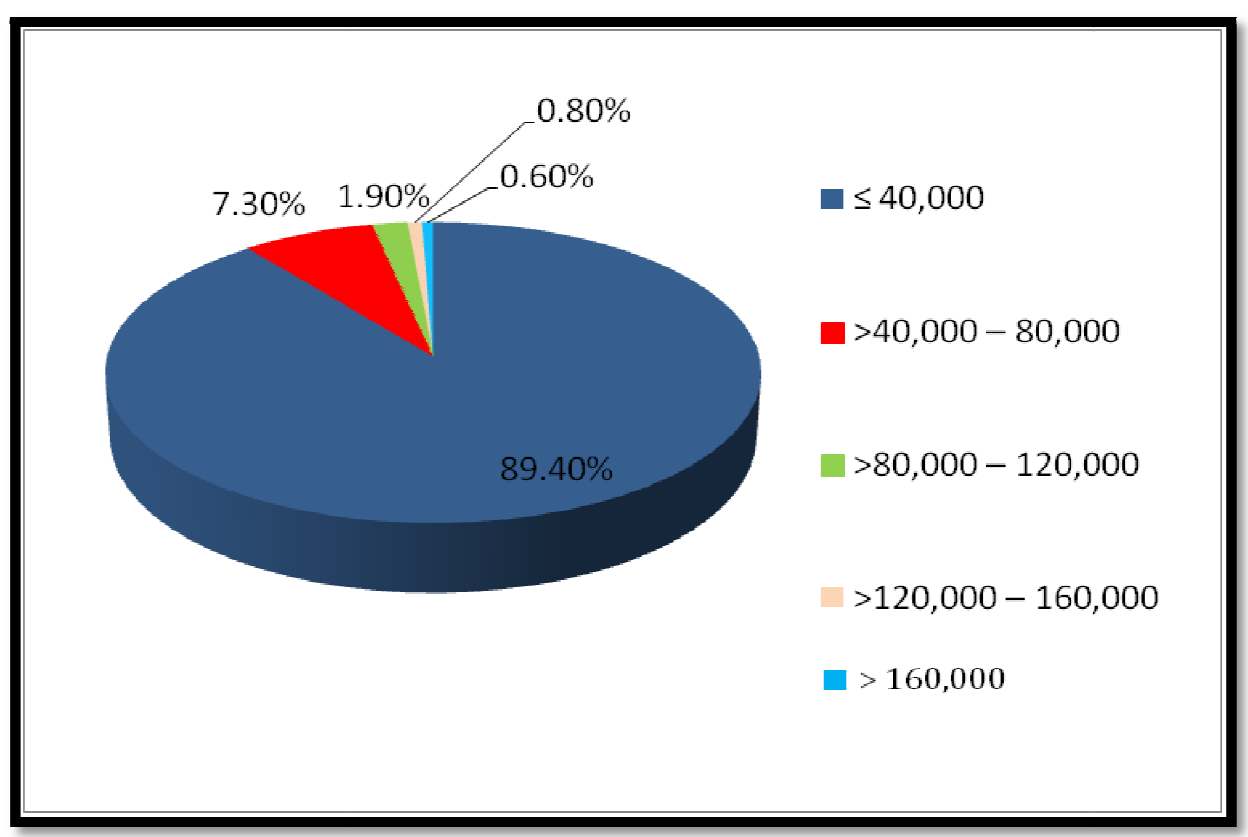

Figure 2: Respondents' Monthly Income 


\subsection{Characteristics of Household and Toilet Facilities}

The nature of different toilet facilities in the area is presented in Figure 3. About half (49.9\%) of toilets identified were pit latrines, followed by septic tank toilet (31.30\%). Very few public toilets were mentioned by the respondents. The characteristics of the households influenced the types of toilet and practices of faecal sludge management in the area. Two types of toilets used by the respondents were: pit latrines and septic tank toilet. This agreed with the findings on housing, sanitation and faecal sludge management in Owerri by Ezekweet al.,(2011) who reported that 54\% of sampled population is made up of single-four person households predominately found in the New Owerri Section and Orji sections of the city, while households with above 4 persons are concentrated in the Douglas road areas and around Amakohia. Pit latrine is a common practice of faecal sludge management in Nigeria just like in other African countries. In an assessment carried out in Kintampo district of Northern Ghana by Okechukwuet al., (2012), pit latrine was found to be the predominant form of toilet system in the community (45.6\%). The values obtained in their study were within the $49.9 \%$ obtained in this study for respondents using pit latrines. However, the result contradicts Ezekweet al., (2011) who reported 98\% of households using the water-borne sanitation system including water flush toilets modified into pour-flush toilet and conventional water closet and $2 \%$ with non-improved toilet pit-latrines.

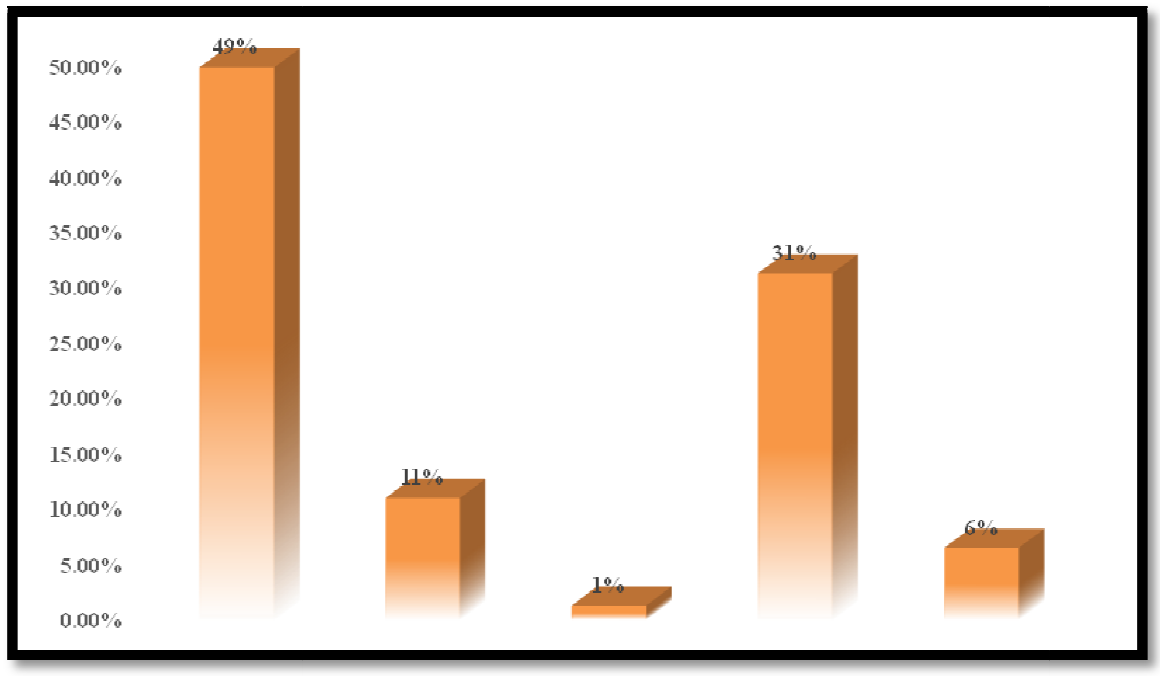

Figure 3: Different Types of Toilet Facilities in the Study Area

\subsection{Respondents' Knowledge on Faecal Sludge Management}

Tables 2 and 3 depict respondent's awareness of effects of faecal sludge on the environment and knowledge of its disposal method, respectively. As many as $69.4 \%$ of respondents were aware that indiscriminate management of faecal sludge affects water, health and environment; there was no association between the faecal waste management knowledge and the respondents' level of education. Awareness could be explained in terms of previous incidents of epidemics such as cholera, diarrhoea in relation to poor excreta management in Nigeria. Majority of respondents $(86.0 \%)$ did not know the fate of the sludge once it was removed from their compounds and (84.0\%) do not know that the sludge could be converted to biogas. Most of the respondents (86.2\%) had knowledge about land disposal method of faecal sludge while few others were aware of additional disposal methods which include, use as feed stock for livestock (5.0\%), agricultural application (5.0\%) and drying and burning $(0.3 \%)$.

There was no association between responses to many questions asked on the knowledge of faecal sludge management such as its impact on the environment and what is done to the sludge removed from their toilet, and demographic characteristics of the respondents: tenants, owners, males, females etc. However, more males (44, 68.8\%) were significantly aware that sludge from their specific tanks could be converted to biogas for domestic use than females $(20,31.2 \%)$. Only a few $(16 \%)$ were aware that the sludge could be converted to biogas might have gotten the awareness from outside the community as biogas generation from faecal sludge had not been practiced in the area before. The same reason might account for the use of faecal sludge as feedstock for livestock and in agricultural application as these were not common practices in the community. Awareness on re-use of faecal sludge is lower in Nigeria compared to some other African countries such as Ghana, Kenya, Tanzania and Uganda. Fred et al., (2014) found that more than half (53.0\%) of the respondents interviewed in southern Ghana disagreed that excreta was waste and were willing to use it as fertilizer resource for agriculture against $5 \%$ of the respondents observed in this study. 


\begin{tabular}{|c|c|c|}
\hline Variables & Frequencies & Percentage (\%) \\
\hline $\begin{array}{c}\text { Whether indiscriminate management of faeces has effect on water, } \\
\text { health and environment }\end{array}$ & & \\
\hline Yes & 277 & 69.4 \\
\hline No & 103 & 25.8 \\
\hline No response & 19 & 4.8 \\
\hline Total & 399 & 100.0 \\
\hline Awareness of what is done to the sludge removed from facilities & & 14.0 \\
\hline Yes & 56 & 86.0 \\
\hline No & 343 & 100.0 \\
\hline Total & 399 & 16.0 \\
\hline Possibility of faecalsludge conversion to biogas for domestic use & & 84.0 \\
\hline Yes & 64 & 100.0 \\
\hline No & 335 & \\
\hline Total & 399 & \\
\hline
\end{tabular}

Table 2: Respondents' Knowledge on Faecal Sludge Management

\begin{tabular}{|c|c|c|}
\hline Options & Frequency & Percentage (\%) \\
\hline Burial & 9 & 2.2 \\
\hline Feed stock for livestock & 20 & 5.0 \\
\hline For agricultural purpose & 20 & 5.0 \\
\hline Reuse for another purpose & 2 & 0.5 \\
\hline Disposed of on land/burying & 344 & 86.2 \\
\hline Dumped in the river & 3 & 0.8 \\
\hline Drying and Burning & 1 & 0.3 \\
\hline Total & 399 & 100.0 \\
\hline
\end{tabular}

Table 3: Respondents' Knowledge on Different Disposal Methods of Faecal Sludge

\subsection{Respondents' Attitude towards Faecal Sludge Management}

Table 4 shows responses towards various attitudinal questions in respect of faecal sludge management. The mean attitudinal score was $9.56 \pm 2.7$ and slightly more than half (51.9\%) of the respondents had positive attitude towards faecal sludge management as shown in Figure 4. As many as $62.4 \%$ had poor attitude that government should be responsible for faecal sludge management in the communities; faecal sludge is very dangerous, so should not be reused (47.9\%) and that feces can be stored together with solid organic waste (Table 4). However, they responded positively towards various attitudes (Figure 4). They were perceived with attitude that people should not dumped waste into stream since stream dumping is the cheapest and convenient method (87.2\%).

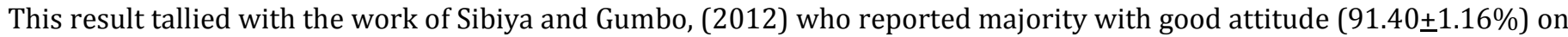
faecal sludge management in Vhembe District of South Africa. This means that they reported hygiene and sanitation as very important aspect of human life because most respondents were always concerned, some were sometimes concerned and a few of them not concerned at all about faecal sludge management. The result of this study was at variance with Montoute and Cashman, (2015) who reported poor attitude of faecal management in their work on assessment of knowledge, attitude and practices on water, sanitation in Anse La Raye Village, Saint Lucia. It also was not at par with the work of Cotton et al., (1995) and Nkansah, (2009) who reported poor attitude and behavior towards faecal sludge management in their studies.

\begin{tabular}{|c|c|c|c|}
\hline Statement & Agree & Disagree & Undecided \\
\hline $\begin{array}{c}\text { Faecal sludge is something that is no more useful and } \\
\text { so, there is no need to spend money for its } \\
\text { management }\end{array}$ & $175(43.9 \%)$ & $196(49.1 \%)$ & $28(7.0 \%)$ \\
\hline $\begin{array}{c}\text { Faecal sludge management is the responsibility of } \\
\text { individual community and government }\end{array}$ & $\begin{array}{c}130 \\
(32.6 \%)\end{array}$ & $249(62.4 \%)$ & $20(5 \%)$ \\
\hline $\begin{array}{c}\text { Faecal sludge is very dangerous, so one should not } \\
\text { reuse it. }\end{array}$ & $159(39.8 \%)$ & $191(47.9 \%)$ & $49(12.3 \%)$ \\
\hline $\begin{array}{c}\text { Since maecal sludge has many beneficial uses. } \\
\text { be storing faeces do not have toilet facility, they can with solid organic waste. }\end{array}$ & $234(58.6 \%)$ & $82(20.6 \%)$ & $83(20.8 \%)$ \\
\hline $\begin{array}{c}\text { It shameful and disgraceful to eat anything produced } \\
\text { from Faecal sludge scurry. }\end{array}$ & $152(38.1 \%)$ & $205(51.4 \%)$ & $16(4.0 \%)$ \\
\hline $\begin{array}{c}\text { Faecal sludge can be used to generate biogas for } \\
\text { cooking }\end{array}$ & $146(36 \%)$ & $120(30.1 \%)$ & $133(33.3 \%)$ \\
\hline $\begin{array}{c}\text { Biogas produced from Faecal sludge cannot be used } \\
\text { as source of electricity at home. }\end{array}$ & $104(26.1 \%)$ & $142(35.6 \%)$ & $153(38.3 \%)$ \\
\hline
\end{tabular}




\begin{tabular}{|c|c|c|c|}
\hline Statement & Agree & Disagree & Undecided \\
\hline $\begin{array}{c}\text { People should be allowed to dump their Faecal sludge } \\
\text { into nearby stream since stream dumping is the } \\
\text { cheapest and convenient method. }\end{array}$ & $29(7.3 \%)$ & $348(87.2 \%)$ & $22(5.5 \%)$ \\
\hline $\begin{array}{c}\text { Dumping of Faecal sludge into streams or rivers will } \\
\text { not affect healthful living of community members }\end{array}$ & $45(11.3 \%)$ & $324(81.2 \%)$ & $30(7.5 \%)$ \\
\hline Faecal sludge reuse is time-consuming & $188(47.1 \%)$ & $107(26.8 \%)$ & $104(26.1 \%)$ \\
\hline It is abomination for people to reuse feces & $115(28.8 \%)$ & $202(50.6 \%)$ & $82(20.6 \%)$ \\
\hline The processes of FSM are time-consuming and costly. & $210(52 \%)$ & $69(17.3 \%)$ & $120(30.1 \%)$ \\
\hline Faecal sludge has many advantages & $307(76.9 \%)$ & $53(13.3 \%)$ & $39(9.8 \%)$ \\
\hline Faecal sludge management can generate employment & $285(71.4 \%)$ & $38(9.5 \%)$ & $76(19.0 \%)$ \\
\hline $\begin{array}{c}\text { Faecal sludge management can reduce disease } \\
\text { conditions }\end{array}$ & $312(78.2 \%)$ & $48(12.0 \%)$ & $39(9.8 \%)$ \\
\hline $\begin{array}{c}\text { Faecal sludge re-use can reduce house hold } \\
\text { expenditure }\end{array}$ & $190(47.6 \%)$ & $95(23.8 \%)$ & $114(28.6 \%)$ \\
\hline Faecal sludge management business is not profitable & $95(23.8 \%)$ & $165(41.4 \%)$ & $139(34.8 \%)$ \\
\hline $\begin{array}{c}\text { Poor people should be involved in Faecal sludge } \\
\text { management business. }\end{array}$ & $174(43.6 \%)$ & $144(36.1 \%)$ & $81(20.3 \%)$ \\
\hline
\end{tabular}

Table 4: Attitude of Respondent toward Faecal Sludge Management

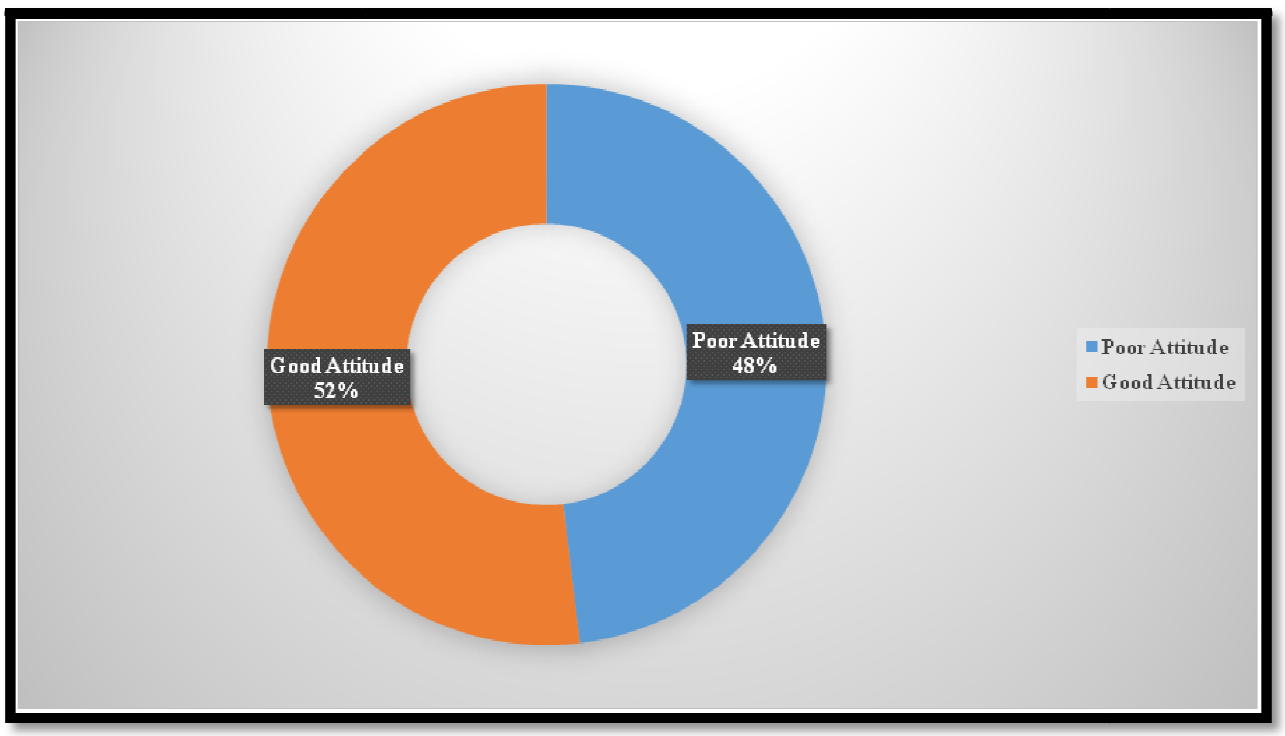

Figure 4: Qualitative Assessment of Respondents' Attitudinal Score (Mean $\pm S D=9.6 \pm 2.7 ;$ Min $=0 ;$ Max= 18)

Table 5 compares respondents' attitude on faecal sludge management and their Socio-demographic Information. Only the level of education was significantly associated to the respondent's attitude.

Generally, the respondents had positive attitude towards faecal sludge management probably because of the danger that is associated with poor handling of the waste. Their positive attitude might have been borne out of passion that indiscriminate and haphazard disposal of faecal sludge into the environment could cause environmental pollution and serious health effects as concluded in previous studies by various researchers (Ingallinellaet al., 2002; Montangeroet al., 2002; Strauss and Montangero, 2002; Parkinson and Tayler, 2003). Some of these health effects include diarrhoea (Jinaduet al., 2004) and transmission of helminth infections that could impede growth and cognitive development of children (Nokeset al., 1992; Esrey, 1996). Besides, positive attitude of the respondents could also be as a result of their moderate level of education. In this study, there was association between the level of respondent's education and their attitude of faecal sludge management. 


\begin{tabular}{|c|c|c|c|c|}
\hline \multirow{2}{*}{$\begin{array}{c}\text { Socio-demographic } \\
\text { Information }\end{array}$} & \multicolumn{2}{|c|}{ Respondents Attitudinal Score } & \multirow[b]{2}{*}{$\chi^{2}$ value } & \multirow[b]{2}{*}{ p value } \\
\hline & $\begin{array}{l}\text { Good Attitude } \\
\text { (Scores of }>9 \text { ) }\end{array}$ & $\begin{array}{l}\text { Poor Attitude (Scores } \\
\text { of less or equal to 9) }\end{array}$ & & \\
\hline $\begin{array}{c}\text { Sex } \\
\text { Male }\end{array}$ & $57.0 \%$ & $52.1 \%$ & \multirow[t]{2}{*}{0.97} & \multirow[t]{2}{*}{0.320} \\
\hline Female & $43.0 \%$ & $47.9 \%$ & & \\
\hline \multicolumn{5}{|l|}{ Level of Education } \\
\hline None Education & $15.0 \%$ & $18.8 \%$ & \multirow{6}{*}{16.20} & \multirow{6}{*}{0.01} \\
\hline Primary education & $16.4 \%$ & $20.3 \%$ & & \\
\hline Secondary education & $28.0 \%$ & $31.8 \%$ & & \\
\hline Tertiary education & $34.8 \%$ & $18.8 \%$ & & \\
\hline Quranic education & $2.9 \%$ & $2.6 \%$ & & \\
\hline Vocational education & $2.9 \%$ & $7.8 \%$ & & \\
\hline \multicolumn{5}{|l|}{ Status of Respondents } \\
\hline Owner & $50.7 \%$ & $39.1 \%$ & \multirow[t]{2}{*}{5.47} & \multirow[t]{2}{*}{0.19} \\
\hline Tenant & $49.3 \%$ & $60.9 \%$ & & \\
\hline \multicolumn{5}{|l|}{ Type of Toilet Facility in Use } \\
\hline None & $5.8 \%$ & $7.3 \%$ & \multirow{5}{*}{9.72} & \multirow{5}{*}{0.05} \\
\hline Pit Latrine & $43.5 \%$ & $56.8 \%$ & & \\
\hline VIP Latrine & $13.0 \%$ & $8.9 \%$ & & \\
\hline Public toilet & $1.0 \%$ & $1.6 \%$ & & \\
\hline Septic Tank & $36.7 \%$ & $25.5 \%$ & & \\
\hline
\end{tabular}

Table 5: Comparison ofRespondents' Attitude on Faecal Sludge Management and

Their Socio-Demographic Information

\subsection{Respondents' Practice of Faecal Sludge Management}

There were several ways by which respondents reacted to full latrines and soak away pits. Most of them immediately emptied, as the pits got full; some closed the pits, while in some cases, the pits were not full as at time of investigation (Figure 5). In terms of patronage, majority of them (82.0\%) patronized manual emptiers (Figure 6). Similarly, when the respondents were asked about who carried out the manual emptying for them, $2.8 \%$ responded that family members did it for them and the rest (97.2\%) said that they engaged services of manual emptiers in the communities.

The factors that determine the choice of any type of emptying service included: cost (21.6\%); availability (29.6\%); quality of service (20.3\%) while various other factors were mentioned by $28.6 \%$ of the respondents. Table 6 shows the cost involved in engaging manual empties for evacuating septic tanks in the communities. In all, many people (92.0\%) paid above twenty thousand naira for emptying their toilet pits using mechanical emptiers. Many of the respondents (68.4\%) appreciated the quality of services rendered by manual empties while few (3.0\%) did not appreciate the quality of their jobs and 28.6\% could not decide. Respondents also blamed the emptiers for their poor reactiontimes to service; cost for emptying, poor service delivery, improper and unhygienic way of disposing of the excreta. These, as well as the poor communication links between the respondents on one hand and the emptiers on the other compound the emptying services delivery problems.

The reason for high cost of evacuation charged by mechanical emptiers was buttressed by Nkansah, (2008) who reported that some of the tanker emptying operators charges according to how far one's latrine is from the nearest regular route. Reason offered is that since many hoses have to be joined in order to reach the pit or tank, more energy is used for siphoning. In a situation where the latrine is completely inaccessible for tanker operators, or the contents of the pits hampers mechanical suction, manual operators have to be employed. The result of this study also disagreed with the work of Nkansah, (2009) who observed lack of knowledge as well as poor attitude and practices toward faecal sludge management in Tamale, Ghana. 


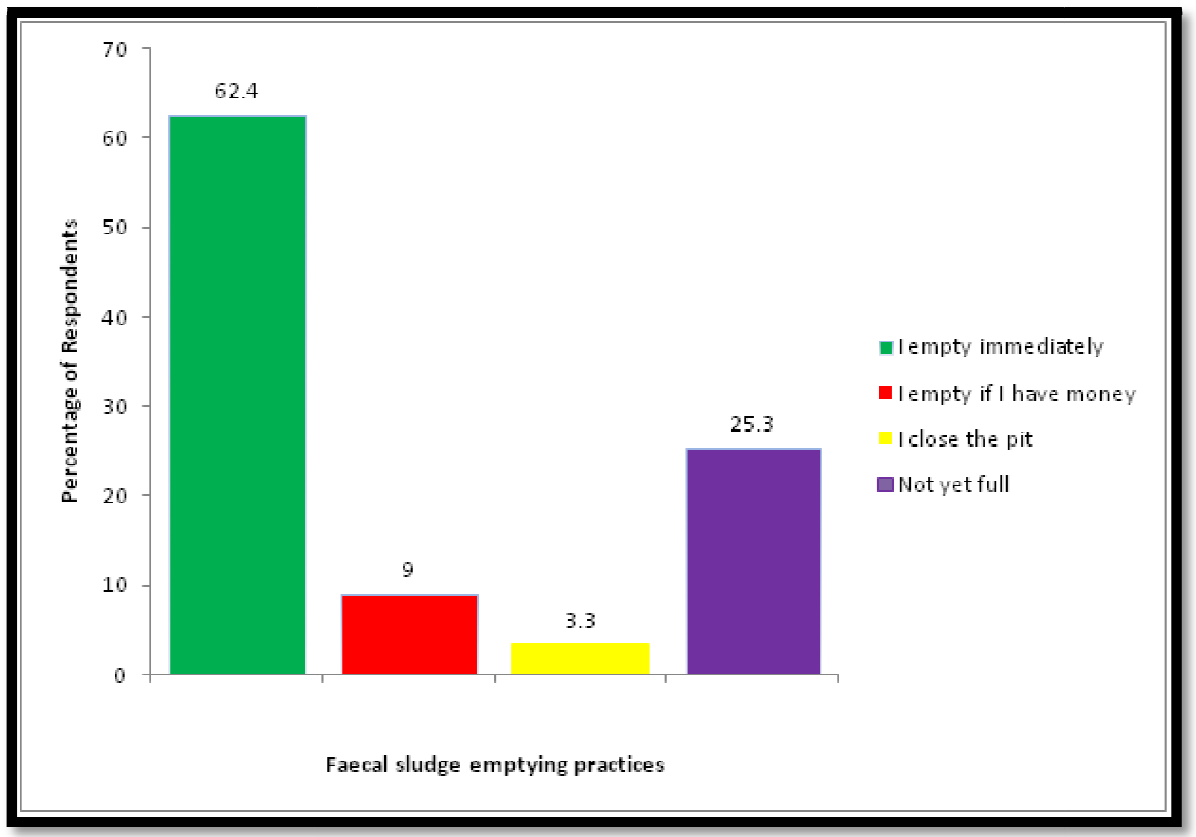

Figure 5: Practices of Faecal Emptying in the Communities

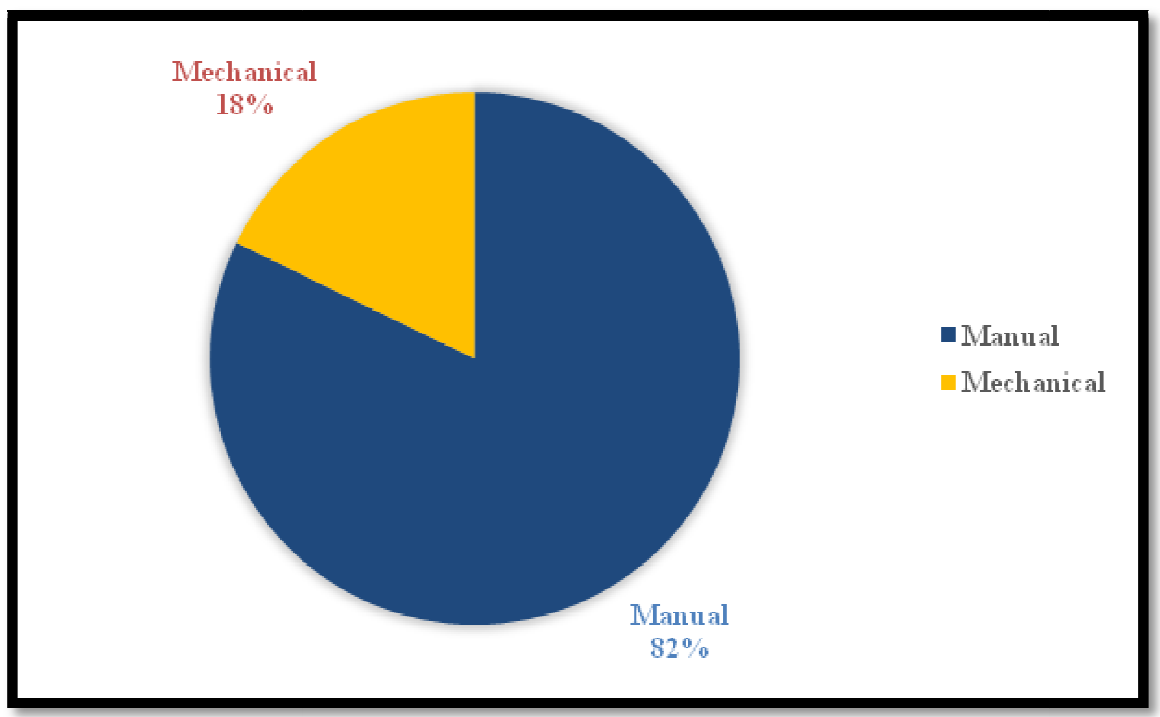

Figure 6: Patronage of Faecal Sludge Emptiers

\begin{tabular}{|c|c|c|}
\hline Cost (N) & Manual & Mechanical \\
\hline $1,000-5,000$ & $37(9.3 \%)$ & $9(2.2 \%)$ \\
\hline $6,000-10,000$ & $80(20.1 \%)$ & $11(2.7 \%)$ \\
\hline $11,000-15,000$ & $49(12.2 \%)$ & $7(1.8 \%)$ \\
\hline $16,000-20,000$ & $11(2.8 \%)$ & $5(1.3)$ \\
\hline$>20,000$ & $222(55.6 \%)$ & $367(92.0 \%)$ \\
\hline Total Table 6: Cost of Engaging Emptiers (In Naira) & $399(100 \%)$ \\
\hline \multicolumn{2}{|c}{} \\
\hline
\end{tabular}

There were no significant differences $(\mathrm{P}>0.05)$ in all of the respondents' faecal sludge management practices and sex of the respondents. That is, sex of the respondents was not significantly associated with the way and manner the respondents addressed issues of full toilets, frequency of emptying and faecal sludge re-use. In contrast, levels of education of the respondents, types of toilet facilities and status of the respondents were significantly $(\mathrm{P}<0.05)$ associated with faecal sludge re-use (Table 7). In addition, there were significant $(\mathrm{P}<0.5)$ associations between the levels of education/types of toilets and what the respondent did when their toilets were full as shown in Tables 8.

The patronage of the manual emptier could probably be linked to unavailability of mechanical emptiers and money charged by them. In the entire city of Abeokuta, there was only one registered mechanical emptier at the time of this study who was not readily available. This finding showed that Abeokuta as a city is under developed when compared to Owerri as reported by Ezekweet al., (2011) who reported 95\% householdsfaecal sludge emptying by means of vacuum trucks in Owerri and Orji metropolis of Imo State, Nigeria. This agreed with other developed countries as reported by 
Montanegro and Strauss, (2002) for Bangkok Thailand, Manila Philipines, Jarkata Indonesia and sub- Saharan Africa that urban areas of developing countries are mainly on-site sanitation (OSS) system other than waterborne, sewered sanitation. On-site sanitation comprises non-sewered household and public toilets, aqua privies and septic tanks. While the cities of Bangkok, Manila and Jakarta have $65 \%$ of the houses linked to on-site sanitation systems, those in sub-Saharan African, has more than $75 \%$ of houses served by on-site sanitation systems (Strauss et al., 2003). Also, many of the respondents appreciated the quality of services rendered by manual emptiers because they did not have any alternative. The respondents emptied their toilets immediately it was full owing to their knowledge of negative consequences that might arise if they failed to do so. This is evident from significant associations between the levels of education and what the respondents did when their toilets were full as obtained in this study.

When examined, latrine emptying practices and rates of safe and unsafe emptying in an unplanned community in Dar Es-Salaam (Dar), Tanzania, Marion et al., (2015) found out that the community people delayed emptying as long as possible, used full pits beyond what is safe and resorted to unsafe practices like 'flooding out', in contrary to what was observed in this study.

\begin{tabular}{|c|c|c|c|c|}
\hline \multirow[b]{2}{*}{ Level of Education } & \multicolumn{2}{|c|}{ Faecal Sludge Re-use } & \multirow[b]{2}{*}{$\chi^{2}$ value } & \multirow[b]{2}{*}{ p value } \\
\hline & Yes & No & & \\
\hline None Education & $22.2 \%$ & $13.4 \%$ & \multirow{6}{*}{12.74} & \multirow{6}{*}{0.02} \\
\hline Primary education & $25.9 \%$ & $17.7 \%$ & & \\
\hline Secondary education & $37.0 \%$ & $31.6 \%$ & & \\
\hline Tertiary education & $7.4 \%$ & $29.4 \%$ & & \\
\hline Quranic education & $3.7 \%$ & $3.0 \%$ & & \\
\hline Vocational education & $3.7 \%$ & $4.8 \%$ & & \\
\hline \multicolumn{5}{|l|}{ Types of Toilet Facilities } \\
\hline Pit latrine & $79.6 \%$ & $49.8 \%$ & \multirow{4}{*}{19.76} & \multirow{4}{*}{0.00} \\
\hline VIP latrine & $13.0 \%$ & $13.9 \%$ & & \\
\hline Public toilet & $1.9 \%$ & $1.7 \%$ & & \\
\hline Septic tank & $5.6 \%$ & $34.6 \%$ & & \\
\hline \multicolumn{5}{|l|}{ Status of the Respondents } \\
\hline Owner & $61.1 \%$ & $43.7 \%$ & \multirow[t]{2}{*}{5.31} & \multirow[t]{2}{*}{0.02} \\
\hline Tenant & $38.9 \%$ & $56.3 \%$ & & \\
\hline
\end{tabular}

Table 7: Comparison of Some Demographic Information and Faecal Sludge Re-Use

\begin{tabular}{|c|c|c|c|c|c|}
\hline \multirow[b]{2}{*}{ Level of Education } & \multicolumn{3}{|c|}{ What Respondents did to Full Toilet } & \multirow[b]{2}{*}{$\chi^{2}$ value } & \multirow[b]{2}{*}{ p value } \\
\hline & $\begin{array}{l}\text { Emptying } \\
\text { immediately }\end{array}$ & $\begin{array}{l}\text { Emptying when } \\
\text { there is money }\end{array}$ & $\begin{array}{c}\text { Closing the } \\
\text { pit }\end{array}$ & & \\
\hline None Education & $12.9 \%$ & $30.6 \%$ & $15.4 \%$ & \multirow{6}{*}{27.75} & \multirow{6}{*}{0.023} \\
\hline Primary education & $18.9 \%$ & $22.2 \%$ & $30.8 \%$ & & \\
\hline Secondary education & $32.1 \%$ & $36.1 \%$ & $15.4 \%$ & & \\
\hline Tertiary education & $28.1 \%$ & $5.6 \%$ & $23.1 \%$ & & \\
\hline Quranic education & $3.2 \%$ & $2.8 \%$ & $0.0 \%$ & & \\
\hline Vocational education & $4.8 \%$ & $2.8 \%$ & $15.4 \%$ & & \\
\hline \multicolumn{6}{|l|}{ Types of Toilet Facilities } \\
\hline Pit latrine & $53.0 \%$ & $72.2 \%$ & $69.2 \%$ & \multirow{4}{*}{26.00} & \multirow{4}{*}{0.002} \\
\hline VIP latrine & $15.7 \%$ & $0.0 \%$ & $0.0 \%$ & & \\
\hline Public toilet & $2.0 \%$ & $0.0 \%$ & $0.0 \%$ & & \\
\hline Septic tank & $29.3 \%$ & $27.8 \%$ & $30.8 \%$ & & \\
\hline
\end{tabular}

Table 8: Comparison of Some Demographic Information and What Respondents Did to Full Toilet

\subsubsection{Job Activities of Chief Environmental Health Officer}

- He supervises and coordinates all EHOs in the local government and providing facilities to ensure safe and sound health of the people.

- He assigns his officers to carryout house to house inspection of all the houses in their designated areas.

- The officers issue notice of abatement to those without toilet facilities in order to making sure people put toilet facilities in placement within a time frame.

\subsubsection{Awareness of Faecal Sludge Management in the Area}

- He said that EHO regulate the services of emptiers and that the manual emptiers were difficult to manage.

- As put by him 'the manual emptiers are difficult to catch up because they are afraid of sanctions'.

- The respondent further stated that there was only one registered mechanical emptier in the Local Government though they learnt there were a number of unregistered ones in operation. 
- When asked about the area where the emptiers dumped faecal sludge, the response was thus, 'they do find their means'.

- The respondents said that there were limit to what he can do to control the mechanical emptiers because they were politically connected.

\subsubsection{Interview with the Manual Emptier in Abeokuta South LGA}

\subsubsection{Method of Apprentice}

- None of the respondents learnt the job and there was no compulsory training before anyone could enroll into the job. One of the respondents is a retired soldier who started the job because of demand for the service by the people in the community. According to him: 'I just started it when there was need for the job; you know there is no work a soldier cannot do'.

- When asked about the involvement of women in the job, they all responded that there was not a single woman in the business as the work was too tough for women. They did not attend trainings towards the job but Local Government authorities educated them on health and the need to protect themselves during emptying about two years earlier.

\subsubsection{Process of Faecal Sludge Emptying}

- According to emptiers, the tools required for emptying faecal sludge includes: ladder, two buckets, two shovels and one pick axe, as cited by the respondents.

- The time required to empty a pit depended on the size and content of the faecal sludge.

- Amount of money charged per a pit also depended on the size, contents of the pit and status of the client. Averagely, they charged N15,000. $00 \mathrm{for} 6 \mathrm{ft} x 6 \mathrm{ft} x 7 \mathrm{ft}$ pit.

- They deposited faecal sludge at any hidden place or burying it.

- When asked about difficulties encountered during the work, they mentioned sharp objects that mixed with the faecal sludge which injured them. Examples of the sharp objects mentioned were metal pieces, sticks, broken bottles and stones.

- They all said that they preferred to empty toilet very early in the morning or late in the night to avoid nuisance flies; 'Very early in the morning the flies are not active as in the day', as said by one of them.

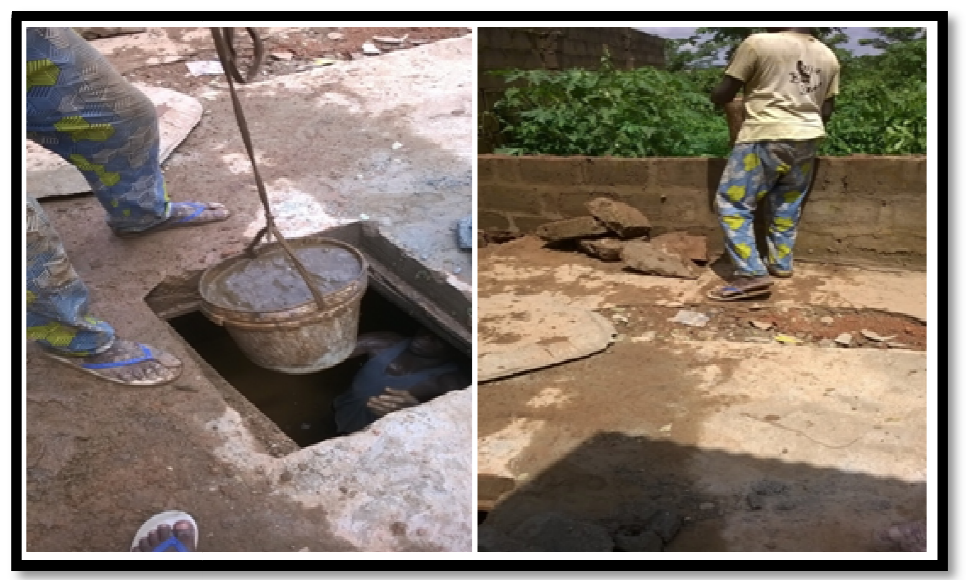

Figure 7: Process of Faecal Sludge Emptying (Manual Pit Emptying)

- In expressing their perceptions toward faecal sludge emptying business, the emptiers responded that the work was too difficult and the reason they charged heavily. According to one of them, 'It is nasty and the smell is too bad to bear, so we often drink hard liquor to help us overcoming the smell and nastiness'.

- They always have diarrhoea, headache, nausea and vomiting as disease they normally contacted from the job.

- When they were asked whether they like faecal emptying job, the response was that they did not like it and could not allow any of their children to do the job because 'it is a dirty job', However, some of them said they felt good with it and educate their children from the money realized from the job.

\section{Conclusion and Recommendations}

\subsection{Conclusion}

In faecal sludge management, effective capacity development and governance for faecal sludge transport, should seek to tackle the problems as well as their knowledge, attitudes and practices. This study showed that pit latrine is a very popular type of toilet facility used in Abeokuta South local government area. Abeokuta south local government area is of medium density with mixture of high- and low-income populations which make their knowledge, attitude and practices of faecal sludge management neither poor nor good. However, respondents' levels of education positively influence their attitude and good practices of faecal sludge management. The residents were ignorant of what happened to the sludge 
thereafter, it was removed from their compounds and did not recycle faecal sludge. In contrast, knowledgeable landlords with pit toilet facility reuse faecal sludge mainly for agriculture. Monitoring of the faecal sludge emptiers should be intensified by the Environmental Health Officer to safe guard the health of the populace and environment moreover, swift action for community education and capacity building in the area of faecal sludge recycling into energy and fertilizer especially at this moment when these two products are getting out of rich of common masses.

\section{References}

i. Cotton, A. Franceys, R. Pickford, J. Saywell, D.1995. On-plot sanitation in low-income urban communities. A review of literature. Water Engineering Development Centre, Loughborough University, United Kingdom.

ii. Esrey, S. A.1996. Water, Waste and Well-being: a Multicountry Study, Vol. 143, No.6, pp. 608-623, American Journal of Epidemiology Han, A.M. and Moe, K. 1990.Household faecal contamination and diarrhoea risk. Journal of Tropical Medicine and Hygiene 93, 333-336.

iii. Ezekwe I.C. Odu, N.N. Ikogori, G. Amos, J. E. 2011. A Preliminary Investigation of Selected Microbial Pollutants in Groundwater Sources inYenegoa Town, Bayelsa Nigeria: Paper Prepared for The Nigerian Journal of Microbiology (In Press).

iv. Fred, N. Kwasi O. Kofi, P. Flwmming, K. Robert, C. A. 2014. Farmers' perception on excreta reuse for peri-urban agriculture in southern Ghana. Journal of DevelopmentandAgricultural Economics, 6(10). 421-428

v. Grover, P. Singh, P. 2014. An analytical study of Effect of family income and size in developing countries. American Research Institute for Policy Development.3(1):127-143.

vi. Ingallinella, A.M. Sanguinetti, G. Koottatep, T. Montangero A. Strauss, M. 2002. The challenge of faecal sludge management in urban areas - strategies, regulations and treatment options. Water Science and Technology.46(10): 285-294.

vii. Iwugo K.O., D’arcy, B. Andoh, R. 2003. Aspects of Land-Based Pollution ofAn African Coastal Megacity of Lagos. Diffuse Pollution Conference, Dublin 2003. Diffuse Pollution Conference, Dublin 2003 Poster Papers: 14-123

viii. Jinadu, M.K. Esmai, O.A. Adegbenro, C.A. 2004.Disposal of children's faeces and implications for the control of childhood diarrhoea. Journal of the Royal Society for the Promotion of Health Volume 124, Issue 6, November 2004, 276-279.

ix. Marion W. J. Oliver C. Sandy, C. 2015.Pit Latrine Emptying Behavior and Demand for SanitationServices in Dar Es Salaam, Tanzania. International; Journal Environmental. Resources Public Health12:2588-2611.

x. Montangero, A. Koné, D. Strauss, M. 2002. Planning Towards Improved Excreta management. In: Proceedings, 5th IWA Conference on Small Water and Wastewater Treatment Systems, Istanbul, Turkey, Sept. 24-26.

xi. Montoute, M.C. Cashman, A. 2015. A knowledge attitudes and practices study on water, sanitation and hygiene in Anse La Rage Village, Saint. Lucia Centre for Resources Management and Environmental studies, Faculty of Science and Technology, theUniversity of the West India, Cave Hill Campus, Barbados.

xii. Nkansah, A. 2008 Appropriate emptying and transport management of faecal sludge in the urban areas of LowIncome countries. PhD research at the Water Engineering Development Centre, Department of Civil and Building Engineering. The University of Loughborough, Loughborough, The United Kingdom.

xiii. Nkansah, A. 2009. Management of faecal Sludge in the urban areas of Low income Countries: a case of Tamale, Ghana, Ph.D Thesis, Loughborough University, United Kingdom.

xiv. Nokes, C. Grantham-McGregor, S.M. Sawyer, A.W. Cooper, E.S. Robinson, B.A. Bundy, D.A.P. 1992 Moderate to heavy infections of Trichuristrichiura affect cognitive function in Jamaican school children. Parasitology, 104: 539-547.

xv. Nokes, C. Grantham-McGregor, S.M. Sawyer, A.W. Cooper, E.S. Robinson, B.A.Bundy, D.A.P. 1992. Moderate to heavy infections of Trichuristrichiura affectcognitive function in Jamaican school children. Parasitology, 104: 539-547.

xvi. Okechukwu O.I. Okechukwu A.A.Noye-Nortey H, Owusu-Agyei2012. Toilet practices among the inhabitants of Kintampo District of Northern Ghana Journal of Medicine and Medical Sciences 3(8) pp. 522-530.

xvii. Parkinson, J. Tayler, K. 2003. Decentralized wastewater management in peri-urban areas countries.Environment and Urbanization.(15), 1:75-90.

xviii. Sibiya, E.J. Gumbo, J. 2013. Knowledge, Attitude and Practices survey on Water, Sanitation and Hygiene in selected schools in Vhember District, Limpopo, South Africa.International Journal of Environmental Resources and Public Health, (10): 2282-2295.

xix. Sivakumar, K., Sugirtharan, M. 2010. Impact of family income and size on per capita solid waste generation: A case study in Manmunia North divisional secretariat division of Batticaloa. Journal Science University Kelaniya (5):13-23.

xx. Strauss, M.Montangero, A. 2002. Capacity Building for Effective Decentralised Wastewater Management. FS Management - Review of Practices, Problems and Initiatives.DFID Engineering Knowledge and Research projectR8056 DFID/GHK.

xxi. Strauss, M., Drescher, S. Zurbrügg, C.Montangero, A. Cofie, O. Drechsel, P. 2003. Co-composting of Faecal Sludge and Municipal Organic Waste.A Literature and State-of-Knowledge Review.S A N D E C / E A W AG/ I W M I

xxii. WHO, 2000.Global Water Supply and Sanitation Assessment. Geneva, World Health Organization. 